PACS 62.20.fq, 81.40.Ef, 81.40.Lm

\title{
Superplasticity of titanium aluminides
}

\author{
R.M. Imayev ${ }^{\dagger}$, V.M. Imayev \\ †renat_imayev@mail.ru \\ Institute for Metals Superplasticity Problems, RAS, 39 Khalturin st., Ufa, 450001, Russia
}

In the present paper, processing methods and superplastic properties of fine-grained $\gamma-\mathrm{TiAl}+\alpha_{2}-\mathrm{Ti}_{3} \mathrm{Al}$ based intermetallic alloys with varying alloy composition have been considered. It has been demonstrated that superplastic behavior is feasible in single-phase $\left(\gamma-\mathrm{TiAl}\right.$ and $\left.\alpha-\mathrm{Ti}_{3} \mathrm{Al}\right)$, two-phase $\left(\gamma-\mathrm{TiAl}+\alpha_{2}-\mathrm{Ti}_{3} \mathrm{Al}\right)$ and three-phase $\left(\gamma-\mathrm{TiAl}+\alpha_{2}-\mathrm{Ti}{ }_{3} \mathrm{Al}+\beta(\mathrm{B} 2)\right)$ alloys. Superplastic properties in the single-phase alloys were reached due to the fact that diffusion processes occur slower in intermetallic alloys in contrast to pure metals; this impeded dynamic grain growth during superplastic flow and promoted superplastic elongations. It has been revealed that processing required for manufacturing of a fine-grained condition is dependent on the alloy composition and can be simplified at transition from peritectically solidifying $\gamma$-TiAl $+\alpha_{2}-\mathrm{Ti}_{3} \mathrm{Al}$ based alloys to $\beta$-solidifying ones. The use of $\beta$-solidifying alloys, which are known to have better chemical homogeneity in contrast to peritectically solidifying $\gamma$-TiAl $+\alpha_{2}-\mathrm{Ti}_{3} \mathrm{Al}$ based alloys, provided enhanced superplastic characteristics. Highest superplastic elongations (up to $\delta=1000 \%$ at $\mathrm{T}=1000^{\circ} \mathrm{C}$ and $\varepsilon^{\prime} \approx 10^{-3} \mathrm{~s}^{-1}$ ) were obtained for the $\beta$-solidifying alloy (Ti-45Al-5Nb-1Mo-0.2B, at. \%) containing a small amount of the $\beta(\mathrm{B} 2)$-phase and subjected to single-step hot forging. Interestingly, superplastic properties were even attained in the as-cast $\beta$-solidifying alloy containing around $20 \mathrm{vol} . \%$ of the $\beta(\mathrm{B} 2)$ phase without any prior hot working.

Keywords: titanium aluminides, fine-grained microstructure, superplasticity

\section{Сверхпластичность алюминидов титана}

В настоящей работе рассмотрены методы обработки и сверхпластичсекие свойства мелкозернистых интерметаллидных сплавов на основе $\gamma-\mathrm{TiAl}+\alpha_{2}-\mathrm{Ti}_{3} \mathrm{Al}$ с различными составами. Показано, что возможно достижение сверхпластического поведения в однофазном $\left(\gamma-\mathrm{TiAl}_{\text {и }} \alpha-\mathrm{Ti}_{3} \mathrm{Al}\right)$, двухфазном $\left(\gamma-\mathrm{TiAl}+\alpha_{2}-\mathrm{Ti}_{3} \mathrm{Al}\right)$ и трехфазном $\left(\gamma-\mathrm{TiAl}+\alpha_{2}-\mathrm{Ti}{ }_{3} \mathrm{Al}+\beta(\mathrm{B} 2)\right)$ сплавах. Сверхпластичские свойства в однофазных сплавах были достигнуты благодаря тому факту, что диффузионные процессы в интерметаллидных сплавах происходят медленнее, чем в чистых металлах; это сдерживает динамический рост зерен при сверхпластичсеком течении и способствует сверхпластическим удлинениям. Было выявлено, что обработка, требуемая для подготовки мелкозернистого состояния, зависит от состава сплава и может быть упрощена при переходе от перитектически затвердевающих сплавов на базе $\gamma$-TiAl+ $\alpha_{2}-\mathrm{Ti}_{3} \mathrm{Al}$ к $\beta$-затвердевающим сплавам. Использование $\beta$ затвердевающих сплавов, которые, как известно, имеют лучшую химическую однородность по сравнению с перитектически затвердевающими сплавами на основе $\gamma$-TiAl+a ${ }_{2}-\mathrm{Ti}_{3} \mathrm{Al}$, привело к повышенным сверхпластическим характеристикам. Наиболее высокие сверхпластические удлинения (до $\delta=1000 \%$ при $\mathrm{T}=1000^{\circ} \mathrm{C}$ и $\varepsilon^{\prime} \approx 10^{-3} \mathrm{c}^{-1}$ были получены для $\beta$-затвердевающего сплава (Ti-45Al-5Nb-1Mo-0.2B, ат. \%), содержащего небольшое количество $\beta($ В2)-фазы и подвергнутого одноступенчатой горячей штамповке. Интересно отметить, что сверхпластичсекие свойства были получены даже в случае литого $\beta$-затвердевающего сплава, содержащего около 20 об. \% фазы $\beta($ В2) без всякой предварительной горячей деформационной обработки.

Ключевые слова: алюминиды титана, мелкозернистая структура, сверхпластичность

\section{Introduction}

In the past 25 years, it has been well documented that brittle intermetallic alloys (based on $\mathrm{TiAl}, \mathrm{Ti}_{3} \mathrm{Al}, \mathrm{NiAl}$ etc.) in a fine-grained condition demonstrated superplastic behavior in a certain temperature-strain rate interval like conventional alloys [1-17]. The phenomenology of superplastic behavior, such as high elongations, low flow stresses, higher strain-rate sensitivity coefficient $(m>0.3)$, as well as deformation mechanisms operating during superplastic flow in intermetallic alloys were found to be similar to those in conventional alloys. The influence of the grain size on superplastic temperatures in the intermetallic alloys was also the same as in conventional alloys. As has been demonstrated for a number of $\gamma$-TiAl based alloys $[2,8,11-13,15,16]$, a decrease in the grain size down to $d \sim 100 \mathrm{~nm}$ led to a significant decrease in the superplastic temperatures. At the same time, there were some features 
Table 1. Intermetallic alloys and processing methods used for producing ultrafine-grained microstructures (LR - lamellae remnants, G/LS mixed globular/lamellar structure)

\begin{tabular}{|c|c|c|}
\hline Alloy / colony/grain size, $\mathrm{d}, \mu \mathrm{m}$ & Processing & Grain size, $d, \mu \mathrm{m}$ \\
\hline \multicolumn{3}{|c|}{ Stoichiometric $\alpha_{2}-\mathrm{Ti}_{3} \mathrm{Al}, \gamma$-TiAl and peritectically solidifying "conventional" $\gamma+\alpha_{2}$ alloys } \\
\hline $\mathrm{Ti}-25 \mathrm{Al} / 200-300$ & 8 forging steps at $\mathrm{T}=1050-650^{\circ} \mathrm{C}$ & 0.1 \\
\hline $\mathrm{Ti}-50 \mathrm{Al} / \sim 100-1000$ & 6 forging steps at $\mathrm{T}=1000-800^{\circ} \mathrm{C}$ & 0.4 \\
\hline $\mathrm{Ti}-46 \mathrm{Al} /$ powder compaction / 30 & $\begin{array}{l}2 \text { forging steps at: } \\
\left.\text { 1) } \mathrm{T}=1000^{\circ} \mathrm{C}, 2\right) \mathrm{T}=750^{\circ} \mathrm{C}\end{array}$ & 0.2 \\
\hline $\mathrm{Ti}-48 \mathrm{Al}-2 \mathrm{Cr}-2 \mathrm{Nb} / 200$ & 20 forging steps at $\mathrm{T}=1000-750^{\circ} \mathrm{C}$ & 0.3 \\
\hline \multicolumn{3}{|c|}{$\beta$-solidifying $\gamma+\alpha_{2}$ alloys } \\
\hline $\mathrm{Ti}-45.2 \mathrm{Al}-1.7 \mathrm{Nb}-1.5 \mathrm{Cr}-0.5 \mathrm{~B} / 200$ & \multirow{2}{*}{$\begin{array}{l}2 \text { forging steps at: } \\
\left.\text { 1) } \mathrm{T}=1200^{\circ} \mathrm{C}, 2\right) \mathrm{T}=950^{\circ} \mathrm{C}\end{array}$} & \multirow{2}{*}{$2-5+L R$} \\
\hline $\mathrm{Ti}-44.2 \mathrm{Al}-0.7 \mathrm{Nb}-1.9 \mathrm{Cr}-0.4 \mathrm{~B} / 90$ & & \\
\hline \multicolumn{3}{|c|}{$\beta$-solidifying $\gamma+\alpha_{2}+\beta$ alloys } \\
\hline $\mathrm{Ti}-45 \mathrm{Al}-5 \mathrm{Nb}-1 \mathrm{Mo}-0.2 \mathrm{~B} / 60$ & 1 forging step at $1200-1100^{\circ} \mathrm{C}$ & $5-10+\mathrm{LR}$ \\
\hline $\mathrm{Ti}-43 \mathrm{Al}-4.5 \mathrm{Nb}-2 \mathrm{Mo}-0.2 \mathrm{~B} / 5-50$ & As-cast condition & $5-50(\mathrm{G} / \mathrm{LS})$ \\
\hline
\end{tabular}

in superplastic behavior of intermetallic alloys as compared with that of conventional alloys. One of them is high superplastic temperatures, which are normally higher than $0.7 T_{m}$ against $0.3-0.5 T_{m}$ ( $T_{m}-$ the melting point $)$ for conventional alloys $[1,3-7,9-10,14,17]$. Other features detected for intermetallic alloys are dynamic recrystalization occurring during superplastic deformation $[1-6,12,16]$ and a strong negative role of twin grain boundaries, the presence of which suppressed superplastic flow $[6,8]$.

In the present work, superplastic behavior of $\gamma$-TiAl $+\alpha_{2}-\mathrm{Ti}_{3} \mathrm{Al}$-based alloys depending on the grain size, the chemical and phase composition, the temperature-strain rate conditions are considered and the mechanisms underlying the superplastic behavior are discussed.

\section{Processing of $\gamma$-TiAl+ $\alpha_{2}-\mathrm{Ti}_{3} \mathrm{Al}$-based alloys}

Superplastic behaviors of titanium aluminides were investigated parallel to designing of novel alloy compositions and processing methods for producing fine-grained microstructures. At first, the stoichiometric Ti-25 at.\%Al and Ti-50 at.\% Al alloys (hereafter Ti-25Al and Ti-50Al) were studied $[2,6,8,13,16]$. The Ti-25Al alloy consisted of the $\alpha_{2}-\mathrm{Ti}_{3} \mathrm{Al}$ phase (superlattice $\mathrm{D} 0_{19}$ ); the second stoichiometric alloy consisted of $\gamma$-TiAl (superlattice $\mathrm{L}_{0}$ ) and $2-3$ vol.\% $\alpha_{2}-\mathrm{Ti}_{3} \mathrm{Al}$ phase. After that, "conventional» peritectically solidifying $\gamma$-TiAl $+\alpha_{2}-\mathrm{Ti}_{3} \mathrm{Al}$ (hereafter $\gamma+\alpha_{2}$ ) alloys containing $2-3$ alloying elements and the $\alpha_{2}$-phase in an amount 5-15 vol.\% were investigated $[15,17]$. In the last decade, $\beta$ solidifying $\gamma+\alpha_{2}[18,19]$ and $\gamma+\alpha_{2}+\beta$ (B2) alloys [20-25] containing reduced aluminum content, $3-5$ alloying elements and the $\beta$ (B2) phase in an amount from zero to about $30 \mathrm{vol} . \%$ were studied. The $\beta$-solidifying alloys attracted interest because these alloys have better chemical homogeneity and relatively fine-grained microstructures in the as-cast condition in contrast to the peritectically solidifying alloys. Improved homogeneity was resulted from avoiding peritectical solidification and refined as-cast microstructure is achieved in the course of the solid-state $\beta=>\alpha$ phase transformation if appropriate alloying elements are used [18-27].

Table 1 represents the alloy compositions, processing methods and microstructural characteristics of the finegrained conditions produced in the alloys. As can be seen, the processing was simplified at transition from "conventional" to $\beta$-solidifying $\gamma+\alpha_{2}$ alloys that was found to be possible owing to refining the as-cast microstructure in the $\beta$-solidifying alloys. The Ti-43Al-4.5Nb-2Mo-0.2B alloy containing around 20 vol. $\%$ of the $\beta$ (B2) phase had refined as-cast microstructure and was not subjected to any hot working. The starting alloys (with the exception of the Ti-46Al alloy) were produced by vacuum arc remelting technique.

The alloy designing thus led to development of processing methods for producing fine- and ultrafinegrained microstructures in $\gamma+\alpha_{2}$ alloys. Initially, multistage isothermal hot forging was used for grain refinement of cast intermetallic alloys. In so doing, the forging temperature gradually decreased from one forging stage to another. The strain rate during forging was chosen in the range of $\varepsilon^{\prime}=5 \times 10^{-4}-5 \times 10^{-3} \mathrm{~s}^{-1}$. The microstructural refinement occurred as a result of dynamic recrystallization. The forging procedure at a certain temperature was fulfilled with a change of the forging direction by $90^{\circ}$ (abc forging) till achievement of a fully recrystallized microstructure because non-recrystallized areas were inherited and retained during subsequent forging at lower temperatures. The microstructural refinement achieved at each forging temperature improved the hot workability of the intermetallic alloys that allowed decreasing the forging temperature from stage to stage. At the same time, the forging temperature was decreased only to a certain temperature, below of which the intermetallic alloy was embrittled. Particularly, in the Ti-25Al alloy the embrittlement was associated with a partial disordering of the $\alpha_{2}$ phase [28]. Using the described forging processing, the workpieces with a homogeneous ultrafine-grained microstructure with a grain size as small as $\mathrm{d}=0.1-0.4 \mu \mathrm{m}$ were manufactured in 


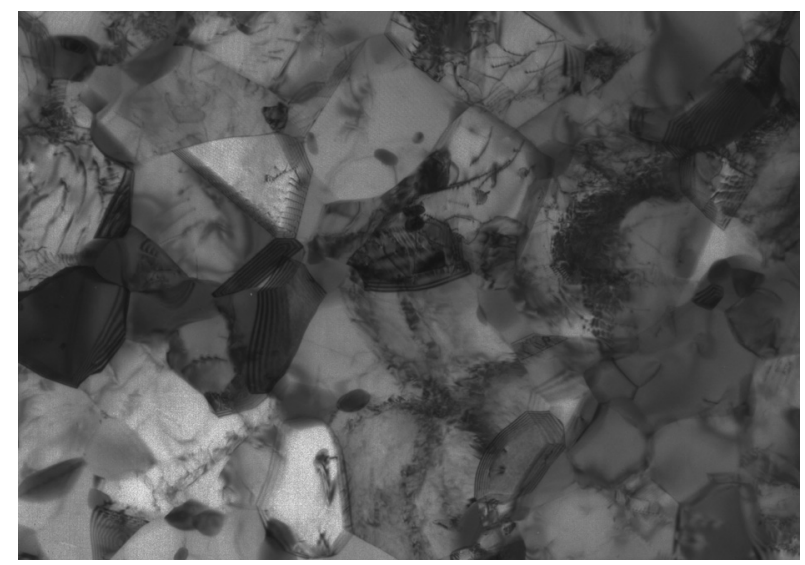

Fig. 1. Ultrafine-grained microstructure $(\mathrm{d}=0.4 \mu \mathrm{m})$ in the stoichiometric Ti-50Al alloy after abc forging.

the stoichiometric and «conventional» $\gamma+\alpha_{2}$ alloys (Fig. 1 and Table 1). An achievement of ultrafine-grained microstructures was of great interest for understanding of a ductile capability of the intermetallic alloys.

Alloying by chromium and niobium in the ingotmetallurgy $\mathrm{Ti}-48 \mathrm{Al}-2 \mathrm{Cr}-2 \mathrm{Nb}$ alloy led to an increase in the forging steps number required for attaining fully recrystallized microstructure. This can be ascribed to the effect of chemical inhomogeneities caused by dendritic segregation, which is characteristic of peritectically solidifying alloys like Ti-48Al-2Cr-2Nb. The microstructure inhomogeneities caused by dendritic segregations promoted localized occurrence of dynamic recrystallization during hot forging that was a reason why so many hot forging steps was applied to produce fully recrystallized ultrafine-grained condition. The use of a powder metallurgy alloy (Ti-46Al) facilitated an achievement of ultrafine-grained microstructure owing to initial relatively fine-grained microstructure and twostep hot forging was found to be enough for producing fully recrystallized ultrafine-grained microstructure [8,11]. For stress relief, the forged workpieces were annealed for 2 hours at a temperature by $50^{\circ} \mathrm{C}$ lower than the last forging step temperature.

Two-step hot working processing with intermediate globularization annealing was used in the case of $\beta$-solidifying $\gamma+\alpha_{2}$ alloys such as Ti-45.2Al-1.7Nb-1.5Cr-0.5B and Ti-44.2Al-0.7Nb-1.9Cr-0.4B (Table 1) [18,19]. On the first step, the ingots were canned using low-carbon steel, preheated and forged at a nominal strain rate of $\varepsilon^{\prime}=10^{-2}-10^{-1} \mathrm{~s}^{-1}$ in the temperature range of the $\alpha+\gamma$ phase field. The die tool was preheated, its temperature was $\mathrm{T}=950^{\circ} \mathrm{C}$. After the first step forging, the workpieces were decanned and subjected to intermediate globularization annealing. The second hot working step was conducted in the same working direction under isothermal conditions at a strain rate of $\varepsilon^{\prime} \sim 10^{-3} \mathrm{~s}^{-1}$ using an isothermal die unit and a glass lubricant. Finally, the forgings were aged at $\mathrm{T}=900^{\circ} \mathrm{C}$ for $\tau=2$ hours, followed by furnace cooling. The produced microstructures were mainly fine-grained although some lamellae remnants were still retained in the forged workpieces.

The $\beta$-solidifying Ti-45Al-5Nb-1Mo-0.2B alloy containing a few amount of the $\beta$ (B2)-phase was subjected to single-step hot forging. To do it, the ingot material was canned using low-carbon steel, preheated and forged at a nominal strain rate $\varepsilon^{\prime}=10^{-2}-10^{-1} \mathrm{~s}^{-1}$ in the temperature range of the $\alpha\left(\alpha_{2}\right)+\beta(B 2)+\gamma$ phase field, $T=1100 \ldots 1200^{\circ} \mathrm{C}[20,21]$. As in the previous case, the die tool temperature was $\mathrm{T}=950^{\circ} \mathrm{C}$. As was demonstrated for the Ti-45Al-5Nb-1Mo-0.2B alloy, such single-step forging procedure can be successfully fulfilled due to the presence of the ductile $\beta$ (B2)-phase, its amount at $1100-1200^{\circ} \mathrm{C}$ was around $10 \mathrm{vol} . \%$. With decreasing the aluminum content and increasing the $\beta$-stabilizing elements content, the $\beta(\mathrm{B} 2)$-phase amount in the as-cast condition increased from about 5 vol.\% in Ti-45Al-5Nb-1Mo- $0.2 \mathrm{~B}$ to about 17 vol.\% in Ti-43Al-4.5Nb-2Mo-0.2B. As a result, the as-cast microstructure in Ti-43Al-4.5Nb-2Mo- $0.2 \mathrm{~B}$ consisted of globular and lamellar constituents and the colony/grain size was relatively fine, $\mathrm{d}=5-50 \mu \mathrm{m}$ (Table 1 ) $[23,24]$. Thus, fine- or near fine-grained microstructure can be obtained in $\beta$-solidifying $\gamma+\alpha_{2}$ alloys using relatively

Table 2. Highest superplastic properties of titanium aluminides (LR - lamellae remnants, G/LS - mixed globular/lamellar structure)

\begin{tabular}{|c|c|c|c|c|c|c|}
\hline Alloy & $\begin{array}{c}\text { Grain size, } d, \\
\mu \mathrm{m}\end{array}$ & $T,{ }^{\circ} \mathrm{C}$ & $\varepsilon^{\prime}, s^{-1}$ & $\mathrm{~d}$ & $\mathrm{~m}$ & Ref. \\
\hline \multicolumn{7}{|c|}{ Stoichiometric $\alpha_{2}-\mathrm{Ti}_{3} \mathrm{Al}, \gamma-\mathrm{TiAl}$ and peritectically solidifying "conventional" $\gamma+\alpha_{2}$ alloys } \\
\hline $\mathrm{Ti}-25 \mathrm{Al}$ & 0.1 & 600 & $6.4 \times 10^{-4}$ & 680 & - & {$[13,16]$} \\
\hline $\mathrm{Ti}-50 \mathrm{Al}$ & 0.4 & 850 & $8.3 \times 10^{-4}$ & 260 & 0.48 & {$[2]$} \\
\hline $\mathrm{Ti}-46 \mathrm{Al}$ & 0.2 & 900 & $1.3 \times 10^{-3}$ & 710 & 0.47 & [11] \\
\hline Ti-48Al-2Nb-2Cr & 0.3 & 800 & $8.3 \times 10^{-4}$ & 355 & 0.56 & {$[15]$} \\
\hline \multicolumn{7}{|c|}{$\beta$-solidifying $\gamma+\alpha$, alloys } \\
\hline $\begin{array}{c}\text { Ti-45.2Al-1.7Nb- } \\
1.5 \mathrm{Cr}-0.5 \mathrm{~B} \\
\end{array}$ & \multirow{2}{*}{$2-5+\mathrm{LR}$} & \multirow{2}{*}{$\begin{array}{l}1050 \\
1000\end{array}$} & $1.3 \times 10^{-3}$ & 750 & - & [19] \\
\hline $\begin{array}{c}\mathrm{Ti}-44.2 \mathrm{Al}-0.7 \mathrm{Nb}- \\
1.9 \mathrm{Cr}-0.4 \mathrm{~B}\end{array}$ & & & $1.3 \times 10^{-3}$ & 780 & - & [19] \\
\hline \multicolumn{7}{|c|}{$\beta$-solidifying $\gamma+\alpha_{2}+\beta$ (B2) alloys } \\
\hline $\begin{array}{c}\text { Ti-45Al-5Nb-1Mo- } \\
0.2 \mathrm{~B} \\
\end{array}$ & $5-10+\mathrm{LR}$ & 1000 & $8.3 \times 10^{-4}$ & 1000 & - & {$[20]$} \\
\hline $\begin{array}{c}\mathrm{Ti}-43 \mathrm{Al}-4.5 \mathrm{Nb}- \\
2 \mathrm{Mo}-0.2 \mathrm{~B}\end{array}$ & 5-50 (G/LS) & 1100 & $1.7 \times 10^{-4}$ & 310 & & {$[22]$} \\
\hline
\end{tabular}


simple hot forging processing or even in as-cast condition in the case of $\gamma+\alpha_{2}+\beta$ (B2) alloys with reduced aluminum content and a higher content of $\beta$-stabilizing alloying elements.

\section{Superplastic behavior of $\gamma$-TiAl $+\alpha_{2}-\mathrm{Ti}_{3} \mathrm{Al}$ based alloys}

As was mentioned, there are some features in superplastic behavior of intermetallic alloys as compared with that of conventional alloys. First of all, it is worth noting high superplastic characteristics obtained for the single-phase Ti-25Al alloy with the grain size $\mathrm{d} \approx 0.1 \mu \mathrm{m}[13,16]$. It is well known [17] that pure metals are not prone to superplastic behavior because of a rapid grain growth, which occurs during superplastic flow at elevated temperatures. Most probably, diffusion processes occur slower in the intermetallic Ti-25Al alloy as compared with pure metals that impeded dynamic grain growth during superplastic flow and provided high superplastic properties [16]. The stoichiometric Ti-50Al alloy demonstrated higher superplastic properties than pure metals but appreciably lower than Ti$25 \mathrm{Al}$ that can be associated with a higher ordering energy of the $\gamma$-TiAl phase as compared with that of the $\alpha_{2}-\mathrm{Ti}_{3} \mathrm{Al}$ phase. Partial disordering occurring in Ti-25Al promoted dislocation mobility and apparently grain boundary sliding as well. Another reason why the Ti-50Al alloy showed lower superplastic properties in comparison with those of the Ti$25 \mathrm{Al}$ alloy was the fact that a low stacking fault energy in the $\gamma$ phase facilitated formation of annealing twins, which impeded grain boundary sliding and promoted dislocation accumulation in the grain interior [16].

Superplastic properties of the $\gamma-\mathrm{TiAl}+\alpha_{2}-\mathrm{Ti}_{3} \mathrm{Al}$ based alloys are improved with increasing the volume fraction of the $\alpha_{2}$ phase. This is probably due to a stabilizing effect of the $\alpha_{2}$ phase on grain growth and formation of annealing twins both during preheating of sample and in the course of superplastic flow $[6,8,16]$. Note that the same was observed in conventional alloys [17]. At the same time, high-temperature mechanical behavior of the ultrafine-grained $\gamma+\alpha_{2}$ alloys significantly depended on both uniformity of the $\alpha_{2}$ phase distribution and the size of the $\alpha_{2}$ phase particles. The $\gamma+\alpha_{2}$ alloys solidifying through peritectic reaction (s) have non-uniform distribution of aluminum and the $\alpha_{2}$ phase and, therefore, are prone to strain localization at elevated temperatures, shown by the formation of macroscopic deformation bands enriched or depleted with the $a_{2}$ phase particles $[11,18]$. This strain localization is avoided in the case of $\beta$-solidifying alloys, which are characterized by a more uniform aluminum distribution than peritectically solidifying alloys $[16,19]$. High superplastic characteristics are reached in the $\beta$-solidifying $\gamma+\alpha_{2}$ alloys even if lamellae remnants are retained along with the fine-grained microstructure [19]. As a rule, the lamellae remnants completely transform into fine equiaxed grains during superplastic flow as a result of dynamic recrystallization and globularization processes, which occur in the course of superpalstic deformation. In this case, the size and morphology of the $\alpha_{2}$ particles have an influence on superplastic properties: the presence of coarse

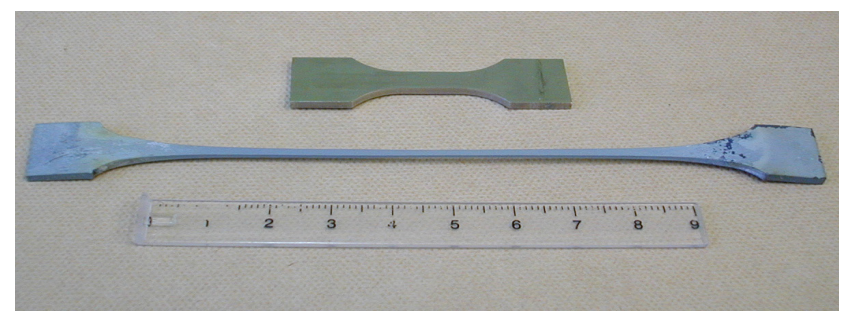

Fig. 2. The specimen of the Ti-45Al-5Nb-1Mo-0.2B alloy tensile strained at $\mathrm{T}=1000^{\circ} \mathrm{C}, \varepsilon^{\prime}=8.3 \times 10^{-4} \mathrm{~s}^{-1}$ to a strain $850 \%$ without failure.

and non-equiaxed $\alpha_{2}$ particles promote the void formation and premature failure. Therefore, globularization annealing deteriorated superplastic properties of the $\gamma+\alpha_{2}$ alloys if microstructural globularization was accompanied by an appreciable growth of the $\alpha_{2}$ particle size leading to higher porosity and lower ductility [19].

The use of the $\beta$-solidifying $\gamma+\alpha_{2}+\beta$ alloys instead of twophase $\gamma+\alpha_{2}$ alloys leads to an increase of the hot workability in as-cast condition due to the refinement of as-cast structure and the presence of the ductile $\beta$ (B2) phase. The presence of the $\beta$ (B2) phase facilitated significantly the hot working and resulted in higher elongations under superplastic conditions (Fig. 2) [20].

If the $\beta$ (B2) phase content is relatively high, as in the Ti-43Al-4.5Nb-2Mo-0.2B alloy, superplastic properties can be reached in as-cast condition without using any hot working or heat treatment $[22,23]$. The presented results have shown that the $\gamma+\alpha_{2}+\beta$ (B2) alloys can be used for superplastic forming processing at relatively moderate temperatures $\left(T=900 \ldots 1100^{\circ} \mathrm{C}\right)$.

\section{Conclusions}

The following conclusions can be drawn from the present work:

1. Superplastic properties were reached in the singlephase Ti-25Al alloy and in the near single-phase Ti-50Al alloy in the ultrafine-grained conditions obtained by multiple hot forging. It was suggested that diffusion processes occur slower in the intermetallic alloys as compared with pure metals and this impeded dynamic grain growth during superplastic flow promoting superplastic elongations.

2. The transition from «conventional» to $\beta$-solidifying alloys containing a large amount of the $\beta$ (B2) phase allows reducing a number of hot working steps during fabrication of fine- or near fine-grained products. As has been demonstrated, superplastic properties are even attained in the as-cast $\beta$-solidifying alloy containing about $20 \mathrm{vol} . \%$ of the $\beta$ (B2) phase without any prior hot working.

3. Superplastic elongations of the $\gamma-\mathrm{TiAl}+\alpha_{2}-\mathrm{Ti}_{3} \mathrm{Al}$ based alloys became higher with increasing the $\alpha_{2}-\mathrm{Ti}_{3} \mathrm{Al}$ phase content and at transition from «conventional» alloys to $\beta$-solidifying ones that can be ascribed to slower dynamic grain growth during superplastic flow in the $\beta$-solidifying alloys as compared with that in the peritectically solidifying $\gamma+\alpha_{2}$ alloys. 
Acknowledgements. The work was supported by Program of fundamental researches of governement academy sciences, registration number 01201455192.

\section{References}

1. M.S. Kim, S. Hanada, S. Watanabe, O. Izumi. Mat. Trans. JIM. 30 (1), 77 (1989).

2. R. M. Imayev and V. M. Imayev. Scr. Met. 25, 2041 (1991).

3. 3. T. Takasugi, S. Rikukawa and S. Hanada. Proceed. Intern. Conf. «Superplasticity in Advanced Materials», edit. S. Hori, M. Tokizane and N. Furushiro, Jap. Soc. Res. Superplast. (1991), p. 329.

4. T. Takasugi, S. Rikukawa and S. Hanada. Acta Metal. 40, 1895 (1992).

5. T. Maeda, M. Okada and Y. Shida. Proceed. Intern. Conf. Superplasticity in Advanced Materials, edit. by Hori S., Tokizane M. and Furushiro N. Jap. Soc. Res. Superplast. (1991) p. 311

6. R. M. Imayev, O. A. Kaibyshev and G. A. Salishchev. Acta Metal. 40, 581 (1992).

7. S. C. Cheng, J. Wolfenstine and O. D. Sherby. Metal Trans. 23A, 1509 (1992).

8. R.M. Imayev, G.A. Salishchev, V.M. Imayev, N.K. Gabdullin and M.R. Shagiev. Mater. Sci. Forum. 170-172, 453 (1994).

9. R.S. Mishra, W. B. Lee, A. K. Mukherjee. Proceed. Intern. Conf. Gamma Titanium Aluminides, ed. by Y.-W. Kim, R. Wagner, M. Yamaguchi. The Minerals, Metals \& Mater. Soc. 571 (1995).

10. C. M. Lombard, A. K. Ghosh and S. L. Semiatin. Proceed. Intern. Conf. Gamma Titanium Aluminides, ed. by Y.-W. Kim, R. Wagner, M. Yamaguchi. The Minerals, Metals \& Mater. Soc. 579 (1995).

11. R. Imayev, M. Shagiev, G. Salishchev, V. Imayev and V. Valitov. Scr. Mat. 34, 985 (1996).

12. V.M. Imayev, R.M. Imayev, G. A. Salishchev. Mater.
Sci. Eng. A208, 226 (1996).

13. R. Imayev, N. Gabdullin and G. Salishchev. Intermetallics. 5, 229 (1997).

14. A. K. Mukherjee and R.S. Mishra. Mater. Sci. Forum. 243-245, 609 (1997).

15. V.M. Imayev, G.A. Salishchev, M.R. Shagiev, A.V. Kuznetsov, R.M. Imayev, O.N. Senkov and F. H. Froes. Scr. Mat. 40, 183 (1999).

16. R. M. Imayev, G. A. Salishchev, O. N. Senkov, V. M. Imayev, M. R. Shagiev, N. K. Gabdullin, A.V. Kuznetsov, F. H. (Sam) Froes. Mater. Sci. Eng. A300, 263 (2001).

17. O.A. Kaibyshev. Superplasticity of commercial alloys. Moscow: Metallurgy, 276 p. (1984). (in Russian)

18. V. M. Imayev, R. M. Imayev, A. V. Kuznetsov. Proc. Symp. «Gamma Titanium Aluminides». TMS. San Diego, USA. 311 (2004).

19. V. M. Imayev, R. M. Imayev, A. V. Kuznetsov. Scr. Mat. 49, 1047 (2003).

20. V.M. Imayev, R.M. Imayev, T.I. Oleneva, T.G. Khismatullin. The Physics of Metals and Metallography. 106 (6), 641 (2008).

21. R. Safiullin, R. Imayev, V. Imayev, W. Beck, Froes F. H. (Sam), and G. Salishchev. Mater. Sci. Forum. 551-552, 441 (2007).

22. V.M. Imayev, T.G. Khismatullin, W. Beck, V. Güther, H.-J. Fecht. Scr. Mater. 57, 193 (2007).

23. V. Imayev, R. Imayev, T. Khismatullin, T. Oleneva, V. Guhter, H.-J. Fecht. Mater. Sci. Forum. 638-642, 235 (2010).

24. V.M. Imayev, T.G. Khismatullin, R. M. Imayev. The Physics of Metals and Metallography. 109 (4), 402 (2010).

25. J. N. Wang, Y. Wang. Inter. J. of Plasticity. 22, 1530 (2006).

26. R. Imayev, V. Imayev, M. Oehring, F. Appel. Intermetallics. 15, 451 (2007).

27. H. Clemens and S. Mayer. Adv. Eng. Mater. 15, 191 (2013).

28. R.M. Imayev, N.K. Gabdullin, G.A. Salishchev, O. N. Senkov, V.M. Imayev and F. H. Froes. Acta Mater. 47, 1809 (1999). 